\title{
Developing the Skills of Students with Mild Intellectual Disabilities Using Interactive Map Applications in a Social Studies Course: An Action Research
}

\author{
Ufuk Karakuş* \\ Gazi University Gazi Faculty of Education, Ankara, Turkey \\ ORCID: 0000-0002-2915-464X
}

Elif İnci Varalan

Gazi University Institute of Educational Sciences, Ankara, Turkey

ORCID: 0000-0002-9541-5684

\begin{tabular}{ll}
\hline \hline Article history & The purpose of this research is developing the skills of students with mild \\
Received: & intellectual disabilities using interactive map applications (Google Maps, \\
& Yandex Maps), determining how to implement the applications, and \\
Received in revised form: & revealing the problems encountered in practice and possible solutions in \\
25.04.2020 & getail. The research is designed in an action research model. The study \\
Accepted: & mild intellectual disability by the Counseling Research Center (CRC) \\
25.04 .2021 & and study in the special education class of a secondary school in Ankara. \\
Key words: & In the research, "Observation Form Concerning the Use of Interactive \\
\hline $\begin{array}{l}\text { Special education, } \\
\text { Mild intellectual disability, }\end{array}$ & $\begin{array}{l}\text { Map Applications" was used in the pre-application, post-application and } \\
\text { Google Maps, }\end{array}$ \\
pandex Maps, & recormanence application. researcher's diary, video and photograph \\
Action research. & the study, the students' ability to use interactive map applications on the \\
phone, computer and smart board was measured and it was determined & that the students' skills were improved. The development of interactive \\
& map use skills of students with mild intellectual disabilities in social \\
& studies lessons contributed to the development of students' direction \\
finding and map literacy skills. In addition, it has been observed that \\
developing these skills contributes to the life skills of students as it \\
increases their self-confidence and improves their abstract thinking \\
skills.
\end{tabular}

\section{Introduction}

With the advancement of technological developments, the use of Global Positioning System (GPS) has increased and many applications have benefited from this technology. These applications (Google Maps, Yandex Maps) allow you to find the location you want in all weather conditions (Verma \& Bhatia, 2013). In addition, the fact that these applications are free increases their use in many areas (Pan, Crotts \& Muller, 2007). Such technological developments have led to many other developments and transformations, especially in the field of education (Edyburn, 2001). These developments have contributed not only to the education 
of individuals with normal development, but also to the development of the skills of individuals who need special education and facilitated their daily life skills (Gierrach \& Stindt, 2009). The use of technology in education and the increase in knowledge and experience of those working in this field have provided new opportunities especially for students who need special education and pave the way for the inclusion of these individuals in social life (Bell, Cihak \& Judge, 2010; Williams, 2005; Petcu, Yell \& Fletcher, 2014).

A group of individuals who need special education consists of those with intellectual disabilities. Mentally disabled individuals are evaluated in four groups. These are mild, moderate, severe and very severe mental disability. However, mental disability covers a wide spectrum. Poor problem solving, behavioral problems, deficiencies in certain basic daily needs, delay in motor skills (walking, running, sitting), difficulties in obeying community rules and many complex care needs are some of the inadequacies valid for these individuals (Alshamri, 2020; McKenzie, McConkey \& Adnams, 2013; Schutzwohl, Koch, Koslowski, Puschner, Voß, Salize, Pfennig \& Vogel., 2016; Wehmeyer, Tassé, Davies \& Stock, 2012). As with all types of disabilities, it is difficult to determine the causes of intellectual disability. in fact, while intellectual disability may have one or more causes, it is difficult to determine exactly what caused it. (Mocanu, Pradais \& Crina, 2020, p.364). Among individuals with intellectual disabilities, there are some with not that significant differences from their peers in their developmental stages. Therefore, these children may not be distinguished until they start school. These individuals may have poor memory, slow learning, difficulty in generalizing what they have learned and understanding language, attention problems, lack of motivation, difficulties in grouping, as well as issues like getting frustrated quickly, and difficulties in adapting to new situations (Ozgur, 2015; Heward, 2009).

Social studies course has an important place for all students, whether they have intellectual disabilities or not. In this lesson, students develop their skills to prepare to use technology, to research using technology, and to create a new perspective (Cogan, Grossman \& Lei, 2000, p. 50). The use of technology is an important first step in preparing the social studies lesson to fulfill its mission (Berson, Diem, Hicks, Mason, Lee \& Dralle, 2000, p.112). In addition, the use of technology has a very important place on the effectiveness of learning applications (Pena-Shaff \& Nicholls, 2004; Tsai \& Tsai, 2003). In addition, in the social studies lesson, students learn to recognize and improve their environment, adapt to the society they live in, be productive, versatile and foster their skills e.g., creative thinking, showing empathy, problem solving and adaptation to current situations (Sonmez-Kartal \& Toper-Korkmaz, 2017, p.180). Students acquire new knowledge in the process of acquiring the objectives targeted in the social studies curriculum and reformat the knowledge by combining the existing knowledge with new information. The activities carried out in the implementation of the social studies curriculum are activities that require interaction with the student's immediate environment. While these activities help to achieve the targeted gains, they allow the student to develop in terms of language and communication (Gezer-Demirdagli, 2017, p.136).

Many materials can be used to gain skills in the social studies curriculum. Maps, one of these materials, have many uses. Maps are used when traveling from one place to another, using GPS, following the weather or current news, or searching for the store you want to go to in a shopping mall, and for many more purposes.

Individuals who need special education can take part in all areas of life and are able to improve themselves in many areas. That said, the lack or insufficiency of any skill makes the lives of these individuals difficult, as is the case with all individuals (Cavus, 2019, p. 26). Especially 
for individuals who need special education, developing map use skills will provide significant benefits in order to make their lives easier for themselves and their families. They will be able to act on their own and overcome their lack of self-confidence.

\section{Purpose of Research and Research Questions}

The general purpose of this research is developing the skills of students with mild intellectual disabilities using interactive map applications (Google Maps, Yandex Maps) in social studies course, determining how to implement the applications, and revealing the problems to be encountered and possible solutions in detail. For this purpose, answers to the following questions were sought.

(1) How was the research process regarding the use of interactive map applications of the students participating in the research?

(2) Is there a significant difference between the pre-application, post-application and permanence application scores of the students participating in the study regarding the use of interactive map applications?

(3) What are the problems encountered in the process of using interactive map applications (Google Maps, Yandex Maps) and possible solutions to these problems?

\section{Method}

\section{Research Model}

This study, is designed in an action research model because of the detailed description of the events experienced in the process, the sharing of the problems experienced in the process and the solutions to these problems, the observations of the researcher in the process and the reporting of the process and the evaluation of the findings obtained cyclically and systematically (Ferrance, 2000, p.1). Action research involves the reflection of systematic and critical thinking. It looks for ways to increase the success of students and improve teaching, seeking solutions to real problems in schools where there is cooperation between colleagues. It includes the systematic collection and analysis of data to improve the quality of a business. It is a research model in which the researcher objectively seeks answers to "what" and "why" questions in the process (Buyukozturk, Cakmak, Akgun, Karadeniz \& Demirel 2018, p. 279; Costello, 2003, p. 5; Cresswell, 2005, p.550; Gay, Mills \& Airasian, 2006, p.499; Onger, 2019, p.65; Yildirim \& Simsek, 2011, p.295).

\section{Selection and Characteristics of the Study Group}

Criterion sampling method, one of the purpose sampling methods, was used in determining the study group. In Criterion sampling, observation units in a study can consist of people, events, objects or situations with certain qualities. In this case, units that meet the criteria determined for the sampling are included in the sampling (Buyukozturk, et al., 2018, p.94-95). Factors such as the fact that the researcher was a teacher for a year in the classroom where the research was conducted and, knew the students, parents and the school administration of the school were determinants in the selection of the study group.

The students in the study group were diagnosed with mild intellectual disability by CRC. These students do not have any disabilities other than mild intellectual disability. In the preliminary interview with the classroom teachers of the students in the study group, it was determined that there was little or no prior knowledge of the students about what the interactive map 
applications were or how they were used. No study had been done with any of the students beforehand on the development of interactive map applications. The research and its content were explained to the students in the study group and they were asked whether they would like to participate in the study. After the students expressed their willingness, a consent form was sent to the parents. The research process started after the participants in the study group signed the consent forms indicating that they participated in the study voluntarily.

Table 1. Personal Information of the Students Participating in the Study

\begin{tabular}{|c|c|c|c|c|c|}
\hline & Gender & Class & Disability & Literacy & $\begin{array}{c}\text { Additional disability / } \\
\text { discomfort }\end{array}$ \\
\hline S1 & M & 7 & $\begin{array}{l}\text { Mild intellectual } \\
\text { disability }\end{array}$ & Literate & Not exist \\
\hline S2 & M & 8 & $\begin{array}{l}\text { Mild intellectual } \\
\text { disability }\end{array}$ & Literate & Not exist \\
\hline S3 & $\mathrm{M}$ & 7 & $\begin{array}{l}\text { Mild intellectual } \\
\text { disability }\end{array}$ & Literate & Not exist \\
\hline
\end{tabular}

When the personal information of the students participating in the research is examined it is reported that all three students are male and withmild intellectual disability and can read and write. In addition, all three students have no additional disability / discomfort other than mild intellectual disability. Two of the students are in the seventh grade, while one is in the eighth grade. All of the students study in a special education class.

\section{Advisory Committee}

In conducting action research, it is very important for field experts to examine the data collection process and the data. In the application process of the research, it is necessary to check the validity of the data and to have a critical perspective. By exchanging opinions with field experts in the advisory committee, the validity of the research is contributed and the research is shaped (Hubbard \& Power, 1993, p.24). In addition, obtaining opinions from experts who are specialized on the subject of the research and who have developed themselves in research methods is important in increasing the validity of the research (Baskale, 2016, p.24). For this purpose, a pre-research advisory committee was established. There are seven experts on the advisory committee. In the research, two experts work as lecturers in Gazi University, Department of Social Studies Teaching and an expert works as a lecturer in the Department of Teaching for the Visually Impaired. While an expert was working as a research assistant in the department of teaching for the visually impaired at the same university, a social studies teacher and two special education teachers participated in the research as an expert.

\section{Data Collection Tools}

Research data are information, observations or situations that are collected or recorded in research. Action research is basically gathering data and making conclusions based on these data (Johnson, 2015, p.79). In this study, the "Observation Form on the Use of Interactive Map Applications" prepared within the scope of the purpose and sub-objectives of the research in consultation with the research committee were used. In addition, observations, researcher's diary, video and photograph records are other data collection tools used in research. 


\section{Data Collection Process}

At the beginning of February, a preliminary meeting was held with the teachers. After the interviews, the action plan was implemented (11.02.2019). The application was carried out on Monday, Tuesday and Wednesday with sessions lasting 50 minutes. After the pre-interviews with the students, the activities prepared by the researcher were applied in the sessions. These activities were presented to the advisory committee on a weekly basis. Some of the activities were arranged according to the performance and levels of the students, and some activities were re-implemented by editing their contents. For the reliability of the research, all sessions were videotaped.

At the end of the study, the observation form was used again and the performances of the students were measured (10.04.2019). As in the pre-application, each student was evaluated separately. One month after the last session, the researcher came together with the students for the permanence application (10.05.2019). Researcher and students did not come together within this one-month period. While planning the research, it was decided to apply permanence at the end of the 1st month, 3rd month and 5th month after the last test. However, only at the end of the first month, the permanent application was made. In the occurrence of this situation, these data could not be collected because the data to be collected in the 3rd month coincided with the month of July and the data to be collected in the 5th month coincided with the month of September. Since the students were on vacation during this time period and S2 graduated at the end of the term, 1-month permanence data was collected.

\section{Data Analysis and Interpretation}

The findings obtained regarding the use of interactive map applications in the research are shown in analytical rubrics. In addition, researcher observations, researcher's diary, video and photograph records were used as qualitative data collection tools and the data obtained from these were analyzed by descriptive analysis. Direct quotations can be used to reflect the views of individuals interviewed or observed through descriptive analysis (Yildirim \& Simsek, 2011, p. 239).

\section{Teaching Materials}

This research is mainly based on the use of interactive map applications. However, in order to use the applications, some pre-learning needs to be realized. For this reason, the researcher included the use of these applications in the process, and activities related to basic map and direction information were applied. The teaching materials used in these activities are listed below.

a) Physical map of the world, b) Physical map of Turkey, c) Map for Turkey and the world to hang on the classroom; these maps were originally posted to the students' own classrooms and brought to the practice class during the application. The relief maps were kept at close range to the students and students were given the opportunity to touch them. Class maps were positioned at a suitable distance to the teaching area, d) A first step atlas map as the possibility of students not having a map in their homes was taken into consideration and the first step atlas map which includes a lot of useful information about the research subject in accordance with their level was used, e) A large size notebook was used to stick the activity sheets applied in the classroom, f) Sketch, compass, map samples, photographs of sea, ocean, and alike were used as a4 size printouts. Photographs were used in the concept teaching sessions, and multiple images of the same concept were included in order to provide diversity in the examples, g) The teaching was carried out with the activity sheets previously prepared by the researcher and pasted on the 
student notebooks at the end of the session, h) Google Earth satellite images since with these visuals, a preliminary preparation was made for interactive applications and location, locationdirection determination and inference studies were made with these images, i) $15 \times 15,9$ piece puzzle; was used in the find instructions activity. Using the instructions, the students found the puzzle pieces hidden in various parts of the school, j) Globe-shaped sponge balls; were used between the applications so that the students both played games and did not stay far from the learning opportunities

\section{Teaching Plan Based on a Sample Lesson Plan}

The social studies lesson "I am Learning the Google Earth Application" study consists of three parts: direct teaching plan, preparation for teaching, teaching process and evaluation session.

Table 2. Direct Teaching Plan for Learning Google Earth Applications

Long-term goal: The student uses interactive map applications.

Short-term goal: The student uses Google Earth to locate a hospital.

Teaching Objectives:

1. The student unlocks the phone.

2. The student opens the Google Earth application.

3. The student writes the name of the hospital in the application.

4. The student creates the route of the hospital.

Material: Cell phone

In the preparation for teaching part, before proceeding to the teaching process, the researcher arranged the application environment in order to use the materials both she and the students would use comfortably and appropriately. Later, the participants were taken to the class, were briefly informed about the session and the rules to be followed were reminded.

In the teaching process section, the steps of the direct teaching method were taken into account. This section consists of introduction to the lesson, motivation, being a model, and controlling. At the beginning of the teaching process, the researcher gave information about what to do in teaching, what she would do and what they would learn at the end. She also explained the rules and the reward (reinforcer) the students would receive at the end of the lesson.

In the motivation part, the researcher gave information about the importance and achievement of the research. "What benefit does doing this bring us?" The answer to the question was considered and the students were motivated to learn.

In the process of being a model, the teacher took the application material and made the application by verbal descriptions. The researcher opened the Google Earth application on her phone, typed the name of a hospital by doing an in-app search, and determined the route. Then, the operations that the students made as models were repeated.

In the checking process, the researcher checked whether the goal was achieved or not. If the student showed sufficient performance for the specified skill, it was described and reinforced. In cases where the student did not show sufficient performance for the specified skill, teaching was renewed, and in cases where the expected criteria were not met, teaching was left to the next session.

The evaluation process consists of guided implementation and independent implementation sections.

In the guided application part, as in the modeling phase, the location of a hospital was searched from the Google Earth application on a mobile phone and the route was determined under the guidance of the researcher. At this stage, the clue was withdrawn and the researcher did not inform the student to do the Google Earth search in the correct steps, but only guided him. If the participant did correctly, it was reinforced, if not, the step of being a model was s returned to.

During the independent implementation process, the student was expected to find the location of the hospital and create a route using the Google Earth maps application. 


\section{Validity, Reliability and Variation in Action Research}

There are three main components in establishing accuracy and reliability in action research. These components are validity, reliability and variation (Johnson, 2015, p. 110).

\section{Validity}

Validity is to what extent a tool or instrument measures what it wants to measure (Johnson, 2015, p.111). In other words, validity is the validity of the measurement results, the level of achievement of the targeted measurement (Buyukozturk et al., 2018, p.121). In this study, field experts were asked to help to ensure validity. Measurement tools applied were presented to social studies (2) and special education (1) experts before the research and they were structured by taking their opinions. In addition, the validity was tried to be increased by conducting interviews with classroom teachers. During the implementation of the measurement tools, the measurement process was carried out considering the factors affecting validity (reliability of measurement results, measurement method and number of items, planner bias, and implementation conditions).

\section{Reliability}

Reliability of the application was calculated by evaluating the videos watched by the observers in the study and by using following formula [(observed researcher behavior / planned researcher behavior)] x 100 (Tekin Iftar \& Kircaali Iftar, 2004, p. 65). Video recordings were delivered to two field experts, special education (1) and social studies (1), of which $30 \%$ of the recorded sessions were determined through unbiased assignment. Field experts followed the records and filled out the reliability form. While calculating the application reliability coefficient the percentage of observed researcher behavior was calculated by dividing the planned researcher behavior. As a result of the calculations, the application reliability of this study was calculated as $93 \%$. The high researcher reliability helped to conclude that the students had achieved the desired gains during the application process.

\section{Variation}

Variation allows seeing a situation in more depth and multidimensional aspects from all angles. Such a variation also helps to increase validity and reliability. Variation in action research takes place for collecting different types of data, using different data sources, collecting data at different times, and reviewing other studies to verify and correct the findings (Johnson, 2015, p. 111). In this study, data were collected with more than one measurement tool (application form, video and photograph records, activity sheets, and student products) to ensure diversity. Data's being collected at different times (pre-application, post-application and permanence application) is another factor that contributes to ensuring diversity. In the research, the findings were supported by other studies in the related field.

\section{Findings and Interpretation}

In this section, findings regarding pre-application, post-application and permanence application regarding the students' use of interactive map applications and quotations in the researcher's diary are included. 
Table 3. Pre-Practice Findings Regarding the Use of Interactive Map Applications

Use of interactive map applications from the phone

Unlocks the phone.

Enters the search engine.

Opens interactive applications.

Writes / tells the microphone home address in the search section of the application.

Writes the name of the hospital in the search section of the application / tells it into the microphone.

Writes / tells the microphone the name of the police station in the search section of the application.

Creates the route.

Use of interactive map applications from the computer

Turns on the computer.
Enters the search engine.
Opens interactive applications.
Writes the home address in the search section of the application.
Writes the name of the hospital in the search section of the
application.
Writes the name of the police station in the search section of the
application.

Creates the route.

Use of interactive map applications from the smart board

Opens the smart board.

Opens the interactive application on the desktop.

Writes the home address in the search section of the application.

Writes the name of the hospital in the search section of the application.

Writes the name of the police station in the search section of the application.

Creates the route.

$\begin{array}{ccc}\begin{array}{c}\text { Completely } \\ \text { With Help }\end{array} & \begin{array}{c}\text { Sometimes } \\ \text { With Help }\end{array} & \begin{array}{c}\text { Without } \\ \text { Any Help }\end{array} \\ \text { (f) } & \text { (f) } & \text { (f) }\end{array}$

$\mathrm{S} 1, \mathrm{~S} 2, \mathrm{~S} 3$

$\mathrm{S} 1, \mathrm{~S} 2, \mathrm{~S} 3$

$\mathrm{S} 1, \mathrm{~S} 2, \mathrm{~S} 3$

$\mathrm{S} 1, \mathrm{~S} 2, \mathrm{~S} 3$

$\mathrm{S} 1, \mathrm{~S} 2, \mathrm{~S} 3$

$\mathrm{S} 1, \mathrm{~S} 2, \mathrm{~S} 3$

$\mathrm{S} 1, \mathrm{~S} 2, \mathrm{~S} 3$

$\begin{array}{ccc}\begin{array}{c}\text { Completely } \\ \text { With Help }\end{array} & \begin{array}{c}\text { Sometimes } \\ \text { With Help }\end{array} & \begin{array}{c}\text { Without } \\ \text { Any Help }\end{array} \\ \text { (f) } & \text { (f) } & \text { (f) }\end{array}$

$\mathrm{S} 1, \mathrm{~S} 2, \mathrm{~S} 3$

$\mathrm{S} 1, \mathrm{~S} 2, \mathrm{~S} 3$

$\mathrm{S} 1, \mathrm{~S} 2, \mathrm{~S} 3$

$\mathrm{S} 1, \mathrm{~S} 2, \mathrm{~S} 3$

$\mathrm{S} 1, \mathrm{~S} 2, \mathrm{~S} 3$

$\mathrm{S} 1, \mathrm{~S} 2, \mathrm{~S} 3$

$\mathrm{S} 1, \mathrm{~S} 2, \mathrm{~S} 3$

\begin{tabular}{ccc}
$\begin{array}{c}\text { Completely } \\
\text { With Help } \\
\text { (f) }\end{array}$ & $\begin{array}{c}\text { Sometimes } \\
\text { With Help } \\
\text { (f) }\end{array}$ & $\begin{array}{c}\text { Without } \\
\text { Any Help } \\
\text { (f) }\end{array}$ \\
\hline- & - & $\mathrm{S} 1, \mathrm{~S} 2, \mathrm{~S} 3$ \\
- & - & $\mathrm{S} 1, \mathrm{~S} 2, \mathrm{~S} 3$
\end{tabular}

$\mathrm{S} 1, \mathrm{~S} 2, \mathrm{~S} 3$

$\mathrm{S} 1, \mathrm{~S} 2, \mathrm{~S} 3$

$\mathrm{S} 1, \mathrm{~S} 2, \mathrm{~S} 3$

$\mathrm{S} 1, \mathrm{~S} 2, \mathrm{~S} 3$

When Table 3 is examined, it is seen that the students do not have any problems while turning on the phone, computer or the smart board, but they need help in the following steps. After interactive map applications were opened on the phone, computer and smart board, the students were able to make the relevant calls completely with help. In the interviews made in the sessions, it was seen that the students used sentences expressing that they had an idea about the use of navigation in the car but did not know how it works. This situation may lead to the conclusion that students encounter interactive map applications in their daily lives, so they have 
the knowledge about these, but no teaching activity related to the use of the applications exists. "... When we started pre-application, they were obviously a little scared. I said this was not a test. I sat next to them and tried to comfort them. After they relaxed, they did their best..." (Researcher's Diary, 11.02.2019)

Table 4. Recent Practice Findings Regarding the Use of Interactive Map Applications

\begin{tabular}{|c|c|c|c|}
\hline Use of interactive map applications from the phone & $\begin{array}{l}\text { Completely } \\
\text { With Help } \\
\text { (f) }\end{array}$ & $\begin{array}{l}\text { Sometimes } \\
\text { With Help } \\
\text { (f) }\end{array}$ & $\begin{array}{l}\text { Without } \\
\text { Any Help } \\
\text { (f) }\end{array}$ \\
\hline Unlocks the phone. & - & - & $\mathrm{S} 1, \mathrm{~S} 2, \mathrm{~S} 3$ \\
\hline Enters the search engine. & - & - & $\mathrm{S} 1, \mathrm{~S} 2, \mathrm{~S} 3$ \\
\hline Opens interactive applications. & - & - & $\mathrm{S} 1, \mathrm{~S} 2, \mathrm{~S} 3$ \\
\hline $\begin{array}{l}\text { Writes / tells the microphone home address in the search section of } \\
\text { the application. }\end{array}$ & - & - & $\mathrm{S} 1, \mathrm{~S} 2, \mathrm{~S} 3$ \\
\hline $\begin{array}{l}\text { Writes the name of the hospital in the search section of the } \\
\text { application / tells it into the microphone. }\end{array}$ & - & - & $\mathrm{S} 1, \mathrm{~S} 2, \mathrm{~S} 3$ \\
\hline $\begin{array}{l}\text { Writes / tells the microphone the name of the police station in the } \\
\text { search section of the application }\end{array}$ & - & - & $\mathrm{S} 1, \mathrm{~S} 2, \mathrm{~S} 3$ \\
\hline Creates the route. & - & - & $\mathrm{S} 1, \mathrm{~S} 2, \mathrm{~S} 3$ \\
\hline Use of interactive map applications from the computer & $\begin{array}{l}\text { Completely } \\
\text { With Help } \\
\text { (f) }\end{array}$ & $\begin{array}{l}\text { Sometimes } \\
\text { With Help } \\
\text { (f) }\end{array}$ & $\begin{array}{c}\text { Without } \\
\text { Any Help } \\
\text { (f) }\end{array}$ \\
\hline Turns on the computer. & - & - & $\mathrm{S} 1, \mathrm{~S} 2, \mathrm{~S} 3$ \\
\hline Enters the search engine. & - & $\mathrm{S} 2, \mathrm{~S} 3$ & S1 \\
\hline Opens interactive applications. & - & $\mathrm{S} 2, \mathrm{~S} 3$ & S1 \\
\hline Writes the home address in the search section of the application. & - & - & $\mathrm{S} 1, \mathrm{~S} 2, \mathrm{~S} 3$ \\
\hline $\begin{array}{l}\text { Writes the name of the hospital in the search section of the } \\
\text { application. }\end{array}$ & - & - & $\mathrm{S} 1, \mathrm{~S} 2, \mathrm{~S} 3$ \\
\hline $\begin{array}{l}\text { Writes the name of the police station in the search section of the } \\
\text { application. }\end{array}$ & - & - & $\mathrm{S} 1, \mathrm{~S} 2, \mathrm{~S} 3$ \\
\hline Creates the route. & - & - & $\mathrm{S} 1, \mathrm{~S} 2, \mathrm{~S} 3$ \\
\hline Use of interactive map applications from the smart board & $\begin{array}{l}\text { Completely } \\
\text { With Help } \\
\text { (f) }\end{array}$ & $\begin{array}{l}\text { Sometimes } \\
\text { With Help } \\
\text { (f) }\end{array}$ & $\begin{array}{c}\text { Without } \\
\text { Any Help } \\
\text { (f) }\end{array}$ \\
\hline Opens the smart board. & - & - & $\mathrm{S} 1, \mathrm{~S} 2, \mathrm{~S} 3$ \\
\hline Opens the interactive application on the desktop. & - & - & $\mathrm{S} 1, \mathrm{~S} 2, \mathrm{~S} 3$ \\
\hline Writes the home address in the search section of the application. & S2 & - & $\mathrm{S} 1, \mathrm{~S} 3$ \\
\hline $\begin{array}{l}\text { Writes the name of the hospital in the search section of the } \\
\text { application. }\end{array}$ & S2 & - & $\mathrm{S} 1, \mathrm{~S} 3$ \\
\hline $\begin{array}{l}\text { Writes the name of the police station in the search section of the } \\
\text { application. }\end{array}$ & S2 & - & $\mathrm{S} 1, \mathrm{~S} 3$ \\
\hline Creates the route. & - & - & $\mathrm{S} 1, \mathrm{~S} 2, \mathrm{~S} 3$ \\
\hline
\end{tabular}

When Table 4 is examined, students appeared successful in using interactive map applications 
on the phone. All of the students independently fulfilled the application steps and were able to use the applications on the phone. When the findings regarding the use of interactive map applications from the computer are examined it is evident that the students received help while entering the search engine and opening the applications and completed the next steps completely without help. When the findings regarding the use of interactive map applications from the smart board are examined it is observed that the students did not have any problems during the opening of the smart board and the application but S2 was able to do so completely with help in the search for relevant places. All students were able to independently create a route on the phone, computer and smart board.

"... While doing the last application, the students came confidently. The reason for this is that they got used to the camera now, they got used to me and there is the confidence of knowing. When the practice started, the situation changed and they were suddenly got nervous. I said to them, "I'm just wondering how much you've learned, I'm not going to grade you out of it." They started to apply it, but they also dropped the eraser and pencils and started looking around. The last application was completed 10-15 minutes later than the pre-application..." (Researcher's Diary, 10.04.2019)

Table 5. Permanence Practice Findings Regarding the Use of Interactive Map Applications

\begin{tabular}{|c|c|c|c|}
\hline Use of interactive map applications from the phone & $\begin{array}{l}\text { Completely } \\
\text { With Help } \\
\text { (f) }\end{array}$ & $\begin{array}{l}\text { Sometimes } \\
\text { With Help } \\
\text { (f) }\end{array}$ & $\begin{array}{c}\text { Without } \\
\text { Any Help } \\
\text { (f) }\end{array}$ \\
\hline Unlocks the phone. & - & - & $\mathrm{S} 1, \mathrm{~S} 2, \mathrm{~S} 3$ \\
\hline Enters the search engine. & - & - & $\mathrm{S} 1, \mathrm{~S} 2, \mathrm{~S} 3$ \\
\hline Opens interactive applications. & - & - & $\mathrm{S} 1, \mathrm{~S} 2, \mathrm{~S} 3$ \\
\hline $\begin{array}{l}\text { Writes / tells the microphone home address in the search section of } \\
\text { the application. }\end{array}$ & - & - & $\mathrm{S} 1, \mathrm{~S} 2, \mathrm{~S} 3$ \\
\hline $\begin{array}{l}\text { Writes the name of the hospital in the search section of the } \\
\text { application / tells it into the microphone. }\end{array}$ & - & - & $\mathrm{S} 1, \mathrm{~S} 2, \mathrm{~S} 3$ \\
\hline $\begin{array}{l}\text { Writes / tells the microphone the name of the police station in the } \\
\text { search section of the application }\end{array}$ & - & - & $\mathrm{S} 1, \mathrm{~S} 2, \mathrm{~S} 3$ \\
\hline Creates the route. & - & - & $\mathrm{S} 1, \mathrm{~S} 2, \mathrm{~S} 3$ \\
\hline Use of interactive map applications from the computer & $\begin{array}{l}\text { Completely } \\
\text { With Help } \\
\text { (f) }\end{array}$ & $\begin{array}{l}\text { Sometimes } \\
\text { With Help } \\
\text { (f) }\end{array}$ & $\begin{array}{l}\text { Without } \\
\text { Any Help } \\
\text { (f) }\end{array}$ \\
\hline Turns on the computer. & - & - & $\mathrm{S} 1, \mathrm{~S} 2, \mathrm{~S} 3$ \\
\hline Enters the search engine. & - & $\mathrm{S} 1, \mathrm{~S} 2, \mathrm{~S} 3$ & - \\
\hline Opens interactive applications. & - & $\mathrm{S} 1, \mathrm{~S} 2, \mathrm{~S} 3$ & - \\
\hline Writes the home address in the search section of the application. & - & - & $\mathrm{S} 1, \mathrm{~S} 2, \mathrm{~S} 3$ \\
\hline $\begin{array}{l}\text { Writes the name of the hospital in the search section of the } \\
\text { application. }\end{array}$ & - & - & $\mathrm{S} 1, \mathrm{~S} 2, \mathrm{~S} 3$ \\
\hline $\begin{array}{l}\text { Writes the name of the police station in the search section of the } \\
\text { application. }\end{array}$ & - & - & $\mathrm{S} 1, \mathrm{~S} 2, \mathrm{~S} 3$ \\
\hline Creates the route. & - & - & $\mathrm{S} 1, \mathrm{~S} 2, \mathrm{~S} 3$ \\
\hline
\end{tabular}




\begin{tabular}{|c|c|c|c|}
\hline Use of interactive map applications from the smart board & $\begin{array}{l}\text { Completely } \\
\text { With Help } \\
\text { (f) }\end{array}$ & $\begin{array}{l}\text { Sometimes } \\
\text { With Help } \\
\text { (f) }\end{array}$ & $\begin{array}{c}\text { Without } \\
\text { Any Help } \\
\text { (f) }\end{array}$ \\
\hline Opens the smart board. & - & - & $\mathrm{S} 1, \mathrm{~S} 2, \mathrm{~S} 3$ \\
\hline Opens the interactive application on the desktop. & - & - & $\mathrm{S} 1, \mathrm{~S} 2, \mathrm{~S} 3$ \\
\hline Writes the home address in the search section of the application. & S2 & $\mathrm{S} 1, \mathrm{~S} 3$ & - \\
\hline $\begin{array}{l}\text { Writes the name of the hospital in the search section of the } \\
\text { application. }\end{array}$ & S2 & $\mathrm{S} 1, \mathrm{~S} 3$ & - \\
\hline $\begin{array}{l}\text { Writes the name of the police station in the search section of the } \\
\text { application. }\end{array}$ & S2 & $\mathrm{S} 1, \mathrm{~S} 3$ & - \\
\hline Creates the route. & - & - & $\mathrm{S} 1, \mathrm{~S} 2, \mathrm{~S} 3$ \\
\hline
\end{tabular}

According to Table 5 Students were able to provide permanent learning in the use of interactive map applications over the phone. The facts that students have phones, family members' use of their phones at home and their interest in technology were effective in the emergence of this situation. All of the students independently fulfilled the application steps and were able to use the applications on the phone. Using the microphone feature while using interactive map applications on the phone is left to the students' preference. When the findings regarding the use of interactive map applications from computers are examined it is understood that the students were able to turn on the computer, but got help from the researcher to enter the search engine and to open the interactive application. This might be related to that students have less computer use, and the computer and internet system in the schoolwork slowly. After the application was opened, the students performed the other application steps independently and were able to use the interactive applications. When the findings regarding the use of interactive map applications from the smart board are examined the following is true the students were able to open the smart board and find the application, but they completely needed help when they wanted to search for home address, hospital and police station places from the search section., In light of this it can be said that the use of smart boards in the classroom is less, the use of teachers is predominant, there is difficulty in finding letters due to the large keyboard part, and in the meantime, attention is distracted. The application occasionally fails due to the expiration of the Google Earth license at the school. When evaluated in general, the students were successful in using interactive applications, they were able to use these applications in various environments by generalizing them in the material. Images of the use of interactive map applications are included in the appendices.

"... When we went to the classroom where we were working, I wondered for how long they could remember our work, so I wanted to chat with them. After a little chat, I switched to the permanence application. There were some things that the students did very confidently, but at some stages they asked me for copies..." (Researcher's Diary, 10.05.2019)

\section{Other Quotations from the Researcher's Diary}

"...Today I brought a picture I drew to the children. They liked the painting very much and according to the picture they drew a car to the east, a ball to the west, a drone to the north and a dog to the south. They liked this activity very much..." (Researcher's Diary, 26.02.2019).

"...Although there are gains of working one-on-one, the students do not like this situation. Because the children do not forget the examples given by each other, the animations we make on the board, the stories I make up, and they have fun together. Although working one-on-one 
gives concrete data on how much progress has been made, I know that students learn better together and by having fun ..." (Researcher's Diary, 27.02.2019).

"...I think the students do not repeat what they learned at home. I assign some tasks as homework, but unfortunately, repeating what they have learned is a habit that students couldn't acquire. That's why we make most of our progress in the classroom and we are limited to the classtime..." (Researcher's Diary, 04.03.2019).

"...The hand skills of children in sketching are very poor, so they behave with prejudice..." (Researcher's Diary, 13.03.2019).

"...When we started to do repetitions about concept teaching, I asked the children who would like to be a teacher. S2 immediately raised his finger. He both explained and showed us the concepts we learned on the map willingly. Then the others became teachers one by one. Being able to explain what you have learned both provides students with permanent information and increases students' self-confidence. When I brought the "Be a teacher, you tell" proposal in the first weeks, none of them volunteered. How much has the situation changed now..." (Researcher's Diary, 18.03.2019).

"... S2 was saying in a few lessons "Even if I close my eyes, I can find the difference between Turkey map and world map." We said let's try it, and we opened relief maps of the same size. S1 closed S2's eyes with his hand so that S2 could not see. S2 put his hands on the map, touched for a long time, and then gave the correct answer. I pretended to change their places and said "tell me now" but in fact I did not change their places. He touched it, waited and gave the correct answer again..." (Researcher's Diary, 18.03.2019).

“... S3 learns quickly. He doesn't want me to remind him when he forgets something he learned. He looks away, thinks and gives the answer..." (Researcher's Diary, 20.03.2019).

“... While planning the research, we created activities according to various levels. But the students are performing better than I expected. That's why we move forward by putting more on the planned activities every week..." (Researcher's Diary, 02.04.2019).

"... The biggest problem I encountered during implementation was distraction. Even if there is a small noise from outside, their attention shifts in this direction. There was a very heavy hail today. I knew they were looking towards the window when I turned my back on them. We stopped studying and watched the it all together..." (Researcher's Diary, 08.04.2019).

\section{Discussion and Conclusion}

In this study, the ability of students with mild intellectual disabilities to use interactive map applications on the phone, computer and smart board was measured, and it was observed that students' skills improved. Students' ability to directly access devices such as phones, tablets and computers at home and their interest in technological devices facilitated the use of these applications. By using the applications, the students were able to search the places covered by the research (their own homes, hospital, and police station). Later, they were able to search the homes of their friends that were not included in the study, and other places they knew, such as markets and shopping places. The students had a lot of fun during the application process and this situation reflected positively on the research results. Students also searched the cities and countries they knew while using the applications. The students made many inferences such as "Syria is very close to us, its border is too long, there is a lot of sea in Turkey, there are islands 
on the seas, Kirikkale is very close to Ankara, My father did his military service in Sirnak, and it is quite far from here". With the use of interactive map applications, it was observed that students' skills of reading, interpreting and abstract thinking about the map improved. Karakus \& Oguz (2013), in their research titled "The use of Google Earth in social studies lesson and teachers' views", concluded that the use of interactive map applications helped the development of skills such as observation, perception of space, and perception of time and chronology. In addition, they stated that these practices contributed to the presentation of concepts such as geographical location, location, and settlement in the social studies curriculum to the students. Ayas, Kaya, Tastan \& Ozder (2015), in the study titled "Using Google Earth images and QGIS open source GIS software in social studies education", they stated the importance of using Google Earth and geographic information systems (GIS) software in the development of students' ability to determine location, direction and location, and to interpret maps. It was underlined that the use of these programs is very important in terms of perceiving the world in which a person lives and understanding the qualities of the place s/he lives in. Although the study groups of the research are different, when the results are evaluated together, it can be said that using interactive map applications contribute to the development of the skills in the curriculum and these applications promote map literacy skills by presenting the relevant concepts to the students in a concrete way. Studies have given similar results in terms of these practices that develop students' map literacy skills and present the concepts concretely to students. Patterson (2007) stated that the use of Google Earth, one of the interactive applications, in education facilitates learning; Ogutveren (2014) stated that Google Earthsupported courses will make education in this field more effective and efficient. In addition, he stated that the knowledge and gains out of using the Google Earth program will improve students' computer skills and enable them to access information easily. When the research results are examined, it can be said that the use of interactive map applications facilitates learning and the results of the research are consistent in terms of making students learn more efficiently by having fun in the sessions where these applications are used.

In the research, it has been determined that students learn better when interacting together. Although one-on-one sessions gave information about how far the students progressed, the students were engaged in effective learning by establishing a dialogue with each other in groups. According to Rogoff, (1990) and Bruner, (1996), dialogue and student interaction play an important role in learning because they allow for the sharing of knowledge, thoughts and goals. As a result, the students create their own knowledge (Flecha, 2000; Edwards \& Mercer, 1987; Vygotsky, 1962; Wells, 1999). As a matter of fact, it has been determined that students with special needs learn better together by interacting and establishing dialogue, increase their vocabulary and these contribute to their literacy skills (Hand, Therrien \& Shelley, 2013).

The skills the social studies program aims to provide, such as critical thinking, perception of space, problem solving, communication, decision-making, observation, map reading and empathy, are basic skills that have a key role in the ability of individuals with intellectual disabilities to act independently and to continue their lives (Yaylaci \& Aksoy, 2017, p.37). Map literacy, one of these skills, has an important place in human life today. In today's age of technology, even devices that show where the vehicles will go are required to read maps or have the most basic map knowledge. This situation has increased the importance of raising individuals with advanced map reading skills (Sonmez, 2010). In addition, maps used in the development of this skill have an important place in understanding geography issues as well as in improving map literacy (Sonmez \& Aksoy, 2013, p.270). Individuals need to have direction finding skills so that they can easily reach where they want to reach, use navigation, and provide addresses and directions. When the results of the current research are evaluated; it can be said 
that the direction finding skills of the students improved and their map literacy skills, which is one of the skills in the social studies curriculum, improved. In addition, the development of interactive map use skills of students with mild intellectual disabilities in social studies course contributes to students' life skills, increases their self-confidence, and their abstract thinking skills. With the positive results achieved, it can be said that it is an exemplary research area for all researchers for future research.

\section{Note}

This research was prepared on the basis of the master's thesis titled "Developing Map Literacy Skills of Special Education Students in Social Studies Lesson", which was completed on 11.12.2019. Gazi University, Ankara/ Turkey, 2019.

\section{References}

Alshamri, K.H. (2020). Challenges and experiences of high school teachers with students having intellectual disabilities in inclusive classrooms in Saudi Arabia, Univers. J. Educ. 8 (5), pp. 2191-2196, DOI: 10.13189/ujer.2020.080559.

Ayas, C., Kaya, H., Tastan, B., \& Ozder, A. (2015). The Use of Google Earth Images and QGIS Open-Source Software in Social Studies Education, International Journal of Geography and Geography Education, 0 (32), pp.43-60. DOI: 10.14781 / mcd.96368.

Baskale, H. (2016). Determination of Validity, Reliability and Sample Size in Qualitative Studies, E-journal of Dokuz Eylul University Nursing Faculty, 9 (1), pp. 23-28, https://dergipark.org.tr/tr/download/article-file/753041.

Bell, S. M., Cihak, D. F., \& Judge, S. (2010). A preliminary study: Do alternative certification route programs develop the necessary skills and knowledge in assistive technology?, International Journal of Special Education, 25(3), pp.111-119, https://eric.ed.gov/?id=EJ909041.

Berson, M., Diem, R., Hicks, D., Mason, C., Lee, J., \& Dralle, T. (2000). Guidelines for Using Technology to Prepare Social Studies Teachers. Contemporary Issues in Technology and Teacher Education, 1(1), pp.107-116. https://citejournal.org/wpcontent/uploads/2016/04/v14i4socialstudies1.pdf.

Bruner, J. (1996). The Culture of Education. Cambridge, MA: Harvard University Press.

Buyukozturk, S., Cakmak, E. K., Akgun, O. E., Karadeniz, S., \& Demirel, F. (2018). Bilimsel araştırma yöntemleri.[Scientific research methods] Ankara: Pegem Publishing.

Cogan, J.J., Grossman, D., \& Lei, M. (2000). Citizenship: The democratic imagination in a global context. Social Education, 64(1), pp.48-52. https://eric.ed.gov/?id=EJ620650.

Costello, P. J. M. (2003). Action research. British Library Cataloguing in Publication Data.

Creswell, J.W. (2005). Educational research: Planning, conducting, and evaluating quantitative and Qualitative research. USA: Pearson Merrill Prentice Hall.

Cavus, E. İ. (2019). Developing Map Literacy Skills of Special Education Students in Social Studies Education. (Unpublished master's thesis), Gazi University Institute of Educational Sciences, Ankara.

Edwards, D., \& Mercer, N. (1987). Common Knowledge: the Development of Joint Understanding in the Classroom. Abingdon: Routledge.

Edyburn, D. L. (2001). Models, theories, and frameworks: Contributions to understanding special education technology. Special Education Technology Practice, 4(2), pp.16-24. https://www.researchgate.net/publication/237677288_Models_Theories_and_Framew orks_Contributions_to_Understanding_Special_Education_Technology 
Ferrance, E. (2000). Action research. LAB at Brown University The Education Alliance.

Flecha, R. (2000). Sharing Words: Theory and Practice of Dialogic Learning. Lanham, MD: Rowman \& Littlefield.

Gay, L.R., Mills, G.E., \& Airasian, P. (2006). Educational research: Competencies for analysis and applications. USA: Pearson Merrill Prentice Hall.

Gezer-Demirdagli, S. (2017). Özel eğitimde sosyal bilgiler eğitimi ve önemi [Social studies education and its importance in special education] M. Sonmez Kartal, O. Toper Korkmaz (Eds.), Özel eğitimde fen bilgisi ve sosyal bilgiler öğretimi [Teaching science and social studies in special education] pp.128-149, Ankara: Pegem Publishing.

Gierrach, J., \& Stindt, K. (2009). Assistive technology for activities of daily living. J. Gierach(Ed.), Assessing Students' Needs for Assistive Technology (ASNAT), 5th Edition. pp.1-16.

Hand, B., Therrien, W., \& Shelley, M. (2013). The effectiveness of argument based teaching \& learning approach for improving the vocabulary, reading, writing ability of students with special needs in inclusive education. Korean J. Spec. Educ. 48, pp.301-317. DOI: 10.3389 / fpsyg.2018.01744

Heward, W.L. (2009). Exceptional children. An introduction to special education. (Ninth Edition). New Jersey: Prentice Hall.

Hubbard, R., \& Power, B. (1993). The art of classroom inquiry. A handbook for teacherresearchers (2nd ed.). Portsmouth: Heinemann.

Johnson, A. P. (2015). Eylem araştırması el kitabı. [A Short Guide to Action Research] Ankara: Anı Publishing.

Karakus, U., \& Oguz, S. (2013). Using Google Earth in Geography Topics in Social Studies Lesson and Teachers Opinions. International Journal of Eurasia Social Sciences, 4 (12), pp.110-125. $125 \% 20$ sibe1\%20o\%c4\%9fuz.pdf http://www.ijoess.com/Makaleler/1402185016_110-

McKenzie J, McConkey R., \& Adnams C. (2013). Health conditions and support needs of persons living in residentuial facilities for adults with intellectual disability in Western Cape Province. S. Afr. Med. J. (103), 481-484. DOI: 10.7196 / samj.6491

Mocanu, L., Pradaiș P., \& Crina, C. (2020). Psycho-Pedagogical Characteristics of Children with Intellectual Disabilities, European Integration - Realities and Perspectives. Proceedings, 15 (1), pp. 362-367.http://proceedings.univ-danubius.ro/index.php/eirp/ article/ view/2052/2094

Ogutveren, M. (2014). The influence of Google Earth Software on the success of teaching geographical topics for the 6th grade students, (Unpublished master's thesis). Giresun University Institute of Social Sciences, Giresun.

Onger, S. (2019). The authentic learning approach in social studies teaching: An action research study (Unpublished doctoral thesis), Gazi University Institute of Educational Sciences, Ankara.

Ozgur, I. (2015). Engelli çocuklar ve eğitimi özel eğitim. [Children with disabilities and their education special education] Adana: Karahan Publishing.

Patterson, T.C. (2007). Google earth as a (not just) geography education tool. Journal of Geography, 0 (106), 145-152. DOI: 10.1080/00221340701678032.

Pan B., Crotts J.C., \& Muller B. (2007). Developing Web-Based Tourist Information Tools Using Google Map. In: Sigala M., Mich L., Murphy J. (Eds.) Information and Communication Technologies in Tourism 2007. Springer, Vienna. DOI: 10.1007 / 978 3-211-69566-1_46

Pena-Shaff, J.B., \& Nicholls, S.C. (2004). Analyzing student interactions and meaning construction in computer bulletin board discussions, Computers \& Education, 42 (3), pp. 243-265. DOI: doi: 10.1016 / j.compedu.2004.02.002 
Petcu, S. D., Yell, M., \& Fletcher, T. (2014). Assistive technology: Legislation and legal issues. Exceptionality, (22), pp.226-236. https://doi.org/10.1080/09362835. 2013. 865538.

Rogoff, B. (1990). Apprenticeship in Thinking: Cognitive Development in Social Context. Oxford: Oxford University Publishing.

Schützwohl M., Koch A., Koslowski N., Puschner B., Voß E., Salize H.J., Pfennig A., \&Vogel A. (2016). Mental illness, problem behaviour, needs and service use in adults with intellectual disability. Social Psychiatry and Psychiatric Epidemiology, (51), pp.767776. DOI: $10.1007 / \mathrm{s} 00127-016-1197-4$.

Sonmez, O. F. (2010). Map skills in primary school social studies education, (Unpublished master's thesis), Gazi University Institute of Educational Sciences, Ankara.

Sonmez, O. F., \& Aksoy, B. (2013). Map Skills and Present of Republic Elementary Scholl Curricula, The Journal of Turkish Social Research, 171 (171), pp.269-288. https://dergipark.org.tr/en/download/article-file/200639.

Sonmez Kartal, M., \& Toper-Korkmaz, O. (Ed.). (2017). Özel eğitimde fen bilgisi ve sosyal bilgiler ögretimi. [Science and social studies teaching in special education] Ankara: Pegem Publishing.

Tekin Iftar, E., \& Kircaali Iftar, G. (2004). Özel ĕgitimde yanlışsız ögrretim yöntemleri. [Correct teaching methods in special education] Ankara: Nobel Publishing.

Tsai, M, J., \& Tsai, C. C. (2003). Information searching strategies in web-based science learning: the role of Internet self-efficacy. Innovations in Education and Teaching International, 40 (1), pp. 43-50, DOI: 10.1080 / 1355800032000038822.

Verma, P., \& Bhatia J. S. (2013). Desing And Development og GPS-GSM Based Trackig System With Google Map Based Monitoring. International Journal of Computer Science, Engineering and Applications (IJCSEA) 3 (3). DOI: 10.5121 / IJCSEA.2013.3304

Vygotsky, L. S. (1962). Thought and Language, (Ed.), A. Kozulin, Cambridge, MA: MIT Pupbilshing. DOI: 10.1037/11193-000

Wehmeyer M.L., Tassé M.J., Davies D.K., \& Stock, S. (2012). Support needs of adulrts with intellectual disability across domains: The role of Technology. Journal of Special Education Technology, 27, pp.11-22. https://www.ncbi. nlm.nih.gov/pmc/articles/PMC4192661/

Wells, G. (1999). Dialogic Inquiry: Toward a Sociocultural Practice and Theory of Education. Boston, MA: Cambridge University Publishing. DOI: 10.1017/ CBO9780511605895

Williams, P. (2005). Using information and communication technology with special educational needs students: The views of frontline professionals. Aslib Proceedings: New Information Perspectives, 57(6), 539-553. DOI: 10.1108 / 00012530510634262

Yaylaci, Z., \& Aksoy, B. (2017). Upskilling Students Who Have Mental Inadequacy with Sence of Direction, Anatolian Journal of Cultural Studies, 1 (1), pp.35-50. http://www.ankad.org/index.php/Ankad/article/view/12

Yildirim, A., \& Simsek, H. (2011). Sosyal bilimlerde nitel araştırma yöntemleri. [Qualitative research methods in the social sciences] Ankara: Seckin Publishing. 


\section{Appendices}

Appendix 1. S1, Calling the Police Station Using a Mobile Phone and Appendix 2. S3 Searching the Location of the School from the Yandex Maps Application
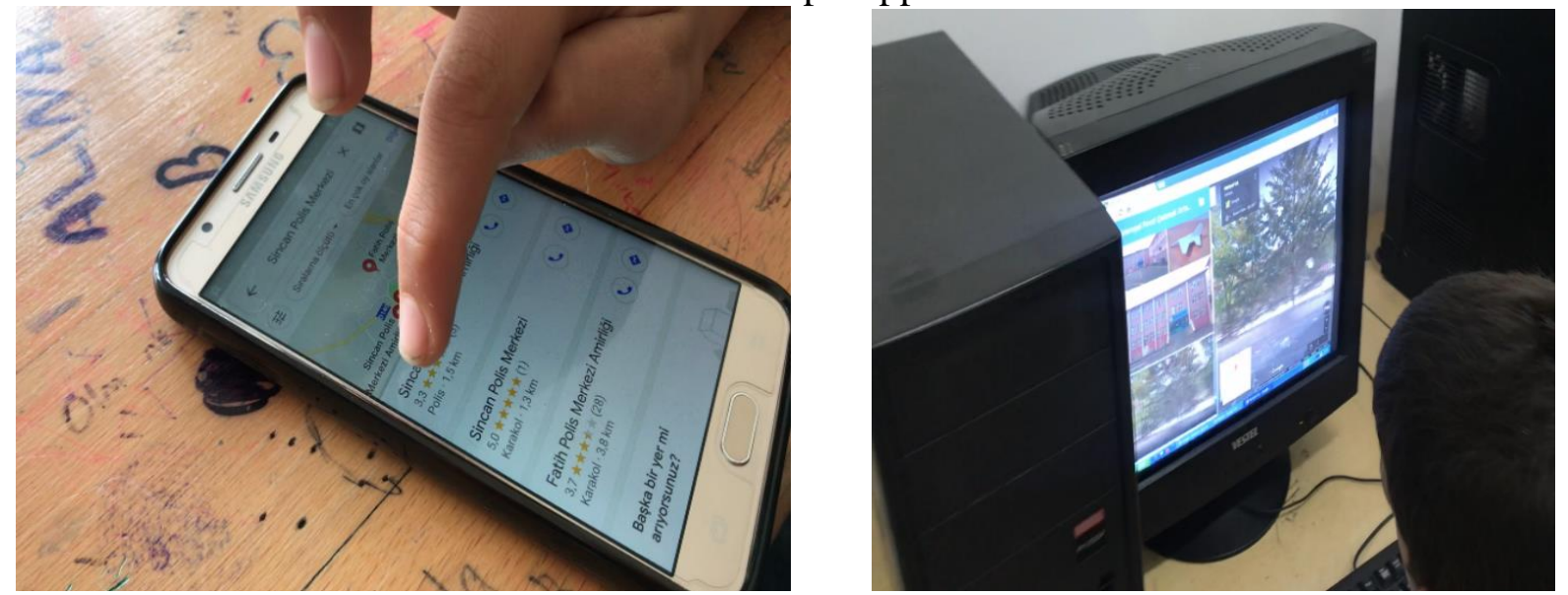

Appendix 3. S1 and S2, Showing the location of Turkey on the Smart Board and Appendix 4. S1, Searching the Homes of Friends Not in the Research Group on the Smart Board
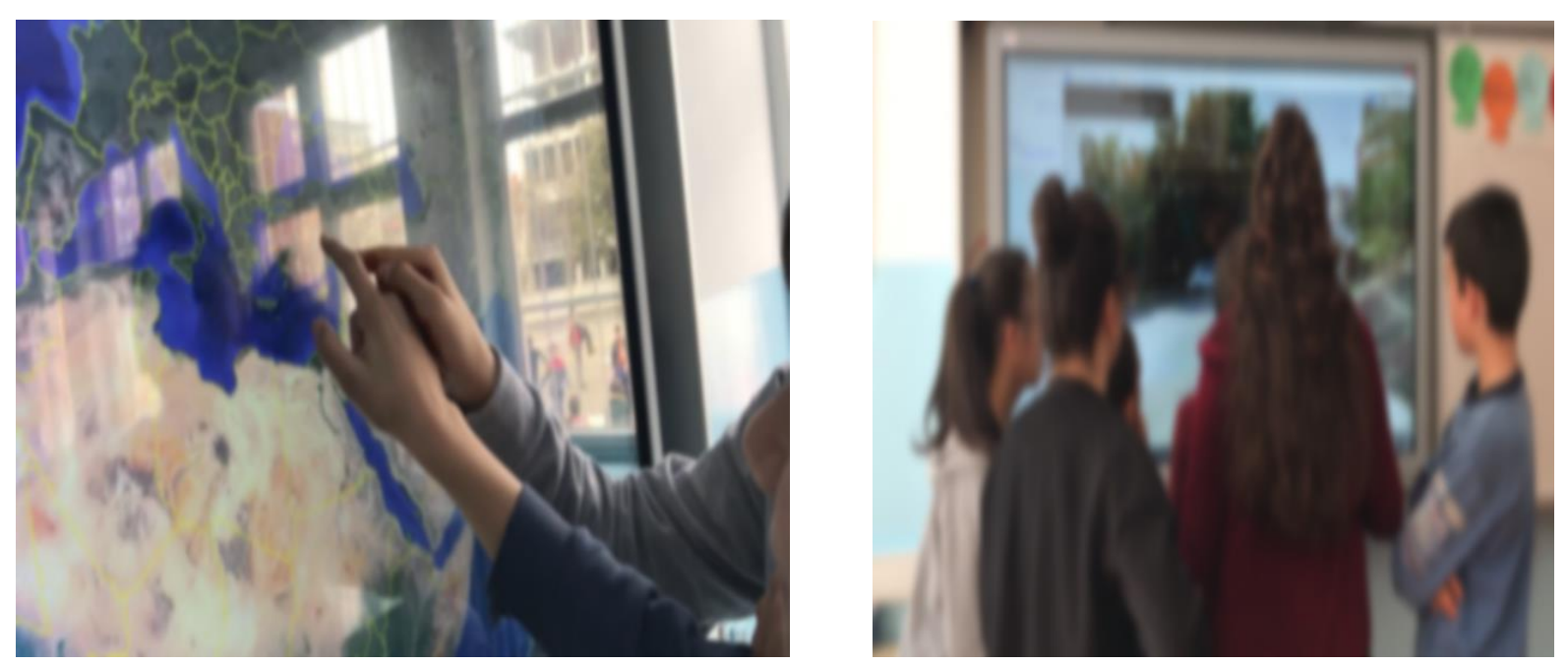